\title{
KOMPARASI PENAFSIRAN AYAT-AYAT PERNIKAHAN BEDA AGAMA
}

\author{
Faisal Haitoni \\ UIN Sunan Kalijaga Yogyakarta \\ faisalth@gmail.com
}

\begin{abstract}
Muhammad Abduh and Ahmad Mustafa al-Maraghi are teachers and students. As a student of Muhammad Abduh, of course Mustafa alMaraghi has many similarities. Uniquely, even though the similarities are more prominent, the interpretation of al Maraghi seems more acceptable, considered to be more straightforward, rather than the interpretation produced by Rashid Ridho and his teacher. Regarding the verse above, their interpretation tends to be different. Based on this fact, the authors are interested in examining further how the interpretations of Muhammad Abduh and Mustafa al-Maraghi as modern Mufassir are related to the legal verses in the Qur'an regarding the issue of interfaith marriage. Then the author will do a comparative analysis of their opinions or the results of the methods they use in their interpretation. the author only focuses on the interpretation of interfaith marriage verses in surah al Baqarah 221 and al Maidah 05 according to the interpretation of al-Manar and the interpretation of al-Maraghi. But these two verses are supported by verse 10 of Surat al Mumtahanah.

Muhammad Abduh dan Ahmad Mustafa al-Maraghi adalah seorang guru dan murid. Sebagai seorang murid Muhammad Abduh, tentu saja Mustafa al-Maraghi mempunyai banyak persamaan. Uniknya, meski persamaannya lebih menonjol, namun tafsir al Maraghi tampaknya lebih dapat diterima, dianggap lebih lurus, daripada tafsir yang dihasilkan Rasyid Ridho dan gurunya. Terkait ayat di atas, penafsiran mereka cenderung berbeda. Berdasarkan fakta ini, penulis tertarik untuk mengkaji lebih jauh bagaimana penafsiran Muhammad Abduh dan Mustafa al-Maraghi selaku Mufassir modern terkait ayat-ayat hukum dalam al-Qur'an terkait masalah pernikahan beda agama. Kemudian penulis akan melakukan analisis komparasi terhadap pendapat mereka atau hasil dari metode yang mereka pakai dalam penafsiran mereka. penulis hanya memfokuskan penelitian terhadap penafsiran tentang ayatayat nikah beda agama dalam surah al Baqarah 221 dan al Maidah 05
\end{abstract}


menurut tafsir al-Manar dan tafsir al-Maraghi. Tetapi dua ayat tersebut didukung oleh ayat 10 surat al Mumtahanah.

Keywords: Nikah, Mu'min, Musyrik, Waris, Keluarga

\section{Pendahuluan}

Salah satu persoalan yang menjadi polemik saat ini adalah fenomena pernikahan beda agama. Dalam al-Qur'an pembahasan tentang pernikahan beda agama ini terdapat dalam beberapa ayat di beberapa surah yaitu, surah al-Baqarah [2] 221, dan al-Maidah [5] 5. Dalam ayat ini Allah menjelaskan tentang pernikahan beda agama. Pernikahan beda agama disini adalah pernikahan antara laki-laki muslim dengan perempuan musyrik. Peristiwa di atas menyangkut perkawinan antar agama yang dapat meliputi: perkawinan orang beragama islam (pria/wanita) dengan orang yang beragama non Islam (pria/wanita). Perkawinan antar agama yang dimaksud antara lain adalah :

Calon isteri beragama Islam dan calon suami tidak beragama Islam, baik ablul kitab maupun musyrik. Calon suami beragam Islam dan calon isteri tidak beragama Islam, baik ablul kitab maupun musyrik. ${ }^{1}$

Perkawinan beda agama secara fakta bukanlah isu baru di Indonesia. Namun, secara historis nikah beda agama ini telah menjadi perdebatan di kalangan tokoh-tokoh Islam pada masa sahabat, tabii'in,dan masa berikutnya dan berlanjut hingga sekarang. Lebih-lebih dalam konteks masyarakat plural dan etnis, budaya, agama seperti di Indonesia, kawin beda agama menjadi sebuah fakta yang wajar dan sangat mungkin terjadi. ${ }^{2}$ Dalam agama Islam, memilih pasangan adalah tidak bebas mutlak. Nabi

1 Siti Musdah Mulia, Muslimah Reformis Perempuan Pembaharu Keagamaan,(Bandung : PT Mizan Pustaka,2005) hlm,55.

${ }^{2}$ Nalla Fezy Bazarghand, Pernikeahan Laki-laki Muslim Dengan Wanita Ablu Kitab (Studi Komparatif Pemikiran Rasyid Ridho Dan Yusuf al-Qardhawn), Skripsi Fakultas Syari'ah UIN Sunan Kalijaga Yogyakarta, 2017, hlm 12. 
Muhammad saw telah memberikan kriteria pilihan yang menempatkan agama pada peringkat pertama. Dalam Islam sebenarnya pernikahan haruslah dengan sesama muslim. ${ }^{3}$ Namun faktanya di zaman modern ini, banyak ummat Islam yang tidak peduli lagi mempertimbangkan keagamaan dalam memilih pasangan hidup. Nikah beda agama seakan-akan menjadi trend di sebagian kalangan, khususnya selebritis. Ditambah dengan beredarnya pemikiran ngawur dari kaum liberal yang menghalalkan nikah beda agama karena mereka menganggap bahwa semua agama itu benar. Nikah beda agama pun sering dijadikan modus pemurtadan seorang muslim atau muslimah.

Sebagaimana diketahui bahwa Muhammad Abduh dan Ahmad Mustafa al-Maraghi adalah seorang guru dan murid . Sebagai seorang murid Muhammad Abduh, tentu saja Mustafa alMaraghi mempunyai banyak persamaan. Uniknya, meski persamaannya lebih menonjol, namun tafsir al Maraghi tampaknya lebih dapat diterima, dianggap lebih lurus, daripada tafsir yang dihasilkan Rasyid Ridho dan gurunya. ${ }^{4}$ Terkait ayat di atas, penafsiran mereka cenderung berbeda. Berdasarkan fakta ini, penulis tertarik untuk mengkaji lebih jauh bagaimana penafsiran Muhammad Abduh dan Mustafa al-Maraghi selaku Mufassir modern terkait ayat-ayat hukum dalam al-Qur'an terkait masalah pernikahan beda agama. Kemudian penulis akan melakukan analisis komparasi terhadap pendapat mereka atau hasil dari metode yang mereka pakai dalam penafsiran mereka.

\section{Penafsiran dalam Tafsir al-Manar}

Penafsiran surat al-Baqarah 221

3 Al-Mawarid, Kawin Beda Agama Dalam Legalisasi Hukum Perkawinan Indonesia Perspektif HAM, Vol. XI, No,2 Sept-Jan 2012 . hlm 158

4 Ali Mustafa Ya'qub, Kritik Hadis (Jakarta : Pustaka Firdaus, 2000), hlm 47 .

TAJDID Vol. 17, No. 2, Juli - Desember $2018 \mid 205$ 
Ayat al Quran yang berbicara tentang pernikahan antara pria Muslim dengan wanita musyrik termaktub dalam Qs. Al-Baqarah ayat 221 :

"Dan janganlah kamu menikabi wanita-wanita musyrik, sebelum mereka beriman. Sesunggubnya wanita budak yang mukmin lebih baik dari wanita musyrik, walaupun Dia menarik, hatimu. dan janganlah kamu menikabkan orang-orang musyrik (dengan wanita-wanita mukmin) sebelum mereka beriman. Sesunggubnya budak yang mukmin lebih baik dari orang musyrik, walaupun Dia menarik hatimu. mereka mengajak ke neraka, sedang Allah mengajak ke surga dan ampunan dengan irin-Nya. dan Allah menerangkean ayat-ayat-Nya (perintahperintah-Nya) kepada manusia supaya mereka mengambil pelajaran.

Ada beberapa riwayat yang mengabarkan tentang asbab an nuzul dari ayat di atas diantaranya:

Diriwayatkan dari Ibnu Munzir, Ibnu Hatim, dan al-Wahidi dari Muqatil, dia berkata : ayat ini turun kepada Ibnu Abi Murtsad al Ghawawi, ketika dia meminta izin kepada Rasulallah saw untuk menikahi seorang wanita muda musyrikah yang memiliki kekayaan dan kecantikan. Maka turunlah ayat 221 surat al-Baqarah di atas. ${ }^{6}$

Al Wahidi meriwayatkan dari jalur Assudi dari Abu Malik dari Ibnu Abbas, dia berkata : ayat tersebut turun kepada Abdullah bin Rawahah yang ketika itu memiliki budak wanita berkulit hitam. Pada suatu hari dia marah dengan budaknya dan menamparnya, kemudian dia mendatangi Rasulallah saw dengan memberitahukan kepada beliau tentang hal itu, lalu dia berkata : sungguh saya akan memerdekakannya dan menikahinya. Lalu dia melakukan apa yang dia katakan tersebut. Melihat apa yang dilakukannya itu, sebagian

5 Depag RI, al-Quran dan Terjemahannya, Jakarta : Yayasan Penyelenggara Penterjemah/ Pentafsir al-Quran , 1971

6 Jalaludin Ash Shayuti, Libabun Nuqulil Fii Asbabin Nuzul, Sebabsebab Turunnya Ayat al Quran ( Kairo : Darul Taqwa) hlm 91. 
orang Muslim mencelanya. Mereka berkata : dia menikahi seorang budak wanita, maka turunlah ayat ini. ${ }^{7}$

Rasyid Ridha dalam kitab tafsirnya menafsirkan ayat tersebut sebagai berikut :

وجملة القول أن ما روى فى الاية التي نفسرها الأن متق على أن المراد با المشركة

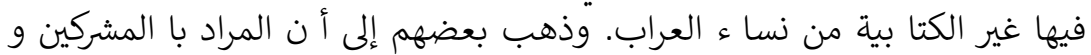

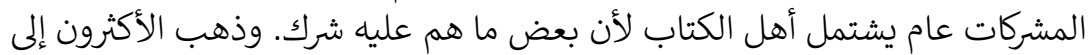

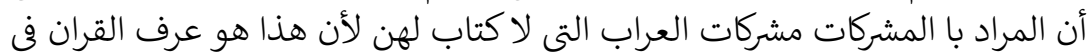

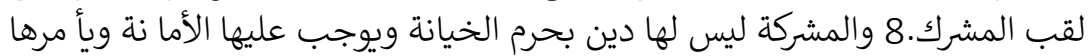

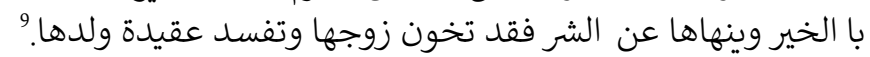
"Sejumlah pendapat sepakat mengatakan bahwa yang dimaksud dengan musyrikat pada ayat yang ditafsirkan sekarang adalah bukan perempuan abli kitab dari perempuan arab. Sebagian ulama berpendapat bahwa yang dimaksud dengan musyrikin dan musyrikat pada ayat di atas bersifat umum termasuk di dalamnya abli kitab, karena sebagian dari merekas syirik. Dan kebanyakan ulama berpendapat bahwa yang dimaksud dengan musyrikat di dalam ayat di atas adalah musyrikat arab yang tidak mempunyai kitab, karena kata syirik pada ayat di atas memang pemahamannya seperti itu. Dan yang dimaksud dengan musyrik adalah perempuan yang tidak, punya agama, dengan mengharamkan khiyanat, mewajibkan amanah, menyeru berbuat amal ma'muf nabi munkar".

Didalam tafsir al-Manar disebutkan bahwa ayat tersebut dengan menyatakan bahwa wanita musyrik yang haram dinikahi oleh pria Muslim dalam surat al-Baqarah ayat 221 di atas adalah wanita musyrik arab yang tidak memiliki kitab suci sebagai pedoman untuk dibaca atau dianut. Karena, seluruh riwayat terkait ayat ini memang mengarah ke pemahaman itu. Adapun orangorang yang mempunyai kitab suci tidak termasuk kedalam kategori musyrik dan secara spontan telah keluar dari hukum pengharaman.

${ }^{7} \mathrm{Ibid}, \mathrm{hlm} 91$

8 Muhammad Rasyid, Tafsir al-Manar (Beirut: Dar al-Kutub al'Ilmiyah, 1947). Cet . I,Juz II, hlm 281.

IIbid, hlm 283. 
Muhammad Abduh menerangkan bahwa jika ada sampai sekarang orang-orang arab yang dimaksud dalam penafsiran di atas maka hukumnya tetap berlaku. Tetapi apabila tidak ada, maka dengan sendirinya tidak ada suatu kepercayaan dan agama pun yang menjadi kendala dalam melangsungkan pernikahan. ${ }^{10}$ Penafsiran kata "Musyrikah" dalam surat al-Baqarah ayat 221 tersebut dengan musyrik arab, menurut Rasyid Ridha adalah pendapat yang sudah disepakati dan didukung oleh Syaikh alMufassirun, yaitu Ibnu Jarir al-Thabari sebagaimana yang dituangkan dalam kitab tafsirnya ${ }^{11}$.

Mengenai terminologi musyrik yang terdapat surat al-Baqarah tersebut, memang at-Thabari dalam tafsirnya juga mengungkapkan beberapa pendapat ulama :

Ayat ini merupakan dalil pengharaman kepada setiap Muslim untuk menikahi wanita musyrik secara general, baik penyembah berhala. Yahudi, Majusi, maupun Nasrani, terkecuali ahli kitab. Hal itu disebabkan adanya ayat yang menasakh keharaman menikahi wanita musyrik. Terminologi ayat di atas dikhususkan bagi wanita musyrik arab saja, meskipun secara zahir nash terlihat mencakup seluruh wanita musyrik. Ayat tersebut mencakup seluruh wanita musyrik tanpa terkecuali, baik penyembah berhala, Majusi, Nasrani maupun ahli kitab, tanpa adanya ayat yang menasakh. ${ }^{12}$

Menurut Rasyid Ridha, dari semua pendapat yang dikemukakan, at-Thabari memposisikan diri berada dan sejalan dengan pendapat Qatadah yaitu pada kelompok kedua yang menyatakan bahwa :

10 Ibid, hlm 281

${ }^{11}$ Ibid, Juz VI, hlm 159

12 Al-Thabari, Jami' al-Bayan fi Ta'mil al Quran ( Cairo : Dar Hijr, 2001), Cet. I, Jilid III, hlm 711-714 


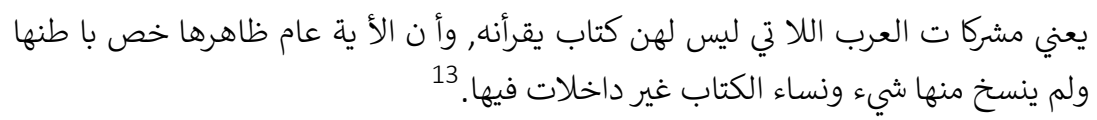

"Terminologi musyrik dalam ayat tersebut dimaksudkan banya bagi musyrikat arab yang tidak memiliki kitab sebagai pedoman untuk. dibaca. Secara zabir, nash itu bersifat umum. Akan tetapi, secara aplikatif bersifat khusus, ayat tersebut juga tidak pernah dinasabk oleh ayat apapun. Oleh karena itu, wanita abli kitab tidak termasuk dalam kategori musyrik."

Rasyid Ridha juga menegaskan bahwa ayat tersebut (pernikahan pria muslim dengan wanita musyrik) tidak pernah menganulir ayat apapun, seperti surat al Maidah ayat 05 yang membolehkan nikah dengan wanita ahli kitab. Rasyid Ridha menganggap sangat tidak logis kalau ayat yang datangnya duluan menganulir ketentuan ayat yang datangnya belakangan. ${ }^{14}$ Pernyataan Rasyid Ridha di atas sangat jelas sekali mengharamkan pria muslim menikah dengan wanita musyrik ( musyrik Mekah). Alasan dari pengharaman tersebut dikatakan Rasyid Ridha adalah karena orang musyrik merupakan faktor yang bisa menjerumuskan atau mengajak pria Muslim ke dalam api neraka, baik dengan faktor perkataan atau perbuatan mereka. Maka, menjalin hubungan dengan mereka dalam bentuk pernikahan merupakan faktor terbesar yang bisa mewujudkan kehinaan masuk ke dalam neraka. ${ }^{15}$

Rasyid Ridha menegaskan dengan bersumpah bahwa menikahi wanita hamba sahaya yang beriman kepada Allah SWT dan Nabi Muhammad SAW jauh lebih bagus dibandingkan menikahi wanita musyrik yang cantik jelita. ${ }^{16}$ Karena, wanita musyrik tersebut tidak mempunyai pedoman yang bisa dijadikan sebagai prinsip dalam kehidupan agar terbiasa dengan kebaikan

${ }^{13}$ Muhammad Rasyid Ridha, Ibid, Juz VI, hlm 158.

${ }_{14}$ Muhammad Rasyid Ridha, Juz II

15 Ibid, hlm 284

${ }^{16}$ Ibid, hlm 282 
dan menjauhi keburukan dan kemungkaran. Wanita musyrik tidak akan merasaa berdosa ketika melakukan penghianatan kepada suaminya. $^{17}$

\section{Penafsiran Surah al-Maidah ayat 05}

Ayat al Quran yang terkait pernikahan antara pria Muslim dengan wanita ahli kitab terdapat dalam surah al-Maidah ayat 05 :

"Pada hari ini Dihalalkan bagimu yang baik-baik. makanan (sembelihan) orang-orang yang diberi Al kitab itu halal bagimu, dan makanan kamu halal (pula) bagi mereka. (dan Dibalalkan mangawini) wanita yang menjaga kehormatan diantara wanita-wanita yang beriman dan wanita-wanita yang menjaga kehormatan di antara orang-orang yang diberi Al kitab sebelum kamu, bila kamu telah membayar mas kawin mereka dengan maksud menikabinya, tidak dengan maksud berivina dan tidak (pula) menjadikannya gundikgundik. Barangsiapa yang kafir sesudab beriman (tidak menerima bukum-bukum Islam) Maka hapuslah amalannya dan ia di hari kiamat Termasuk orang-orang merugi. "18

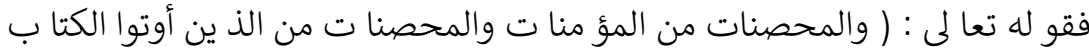

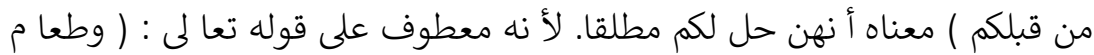

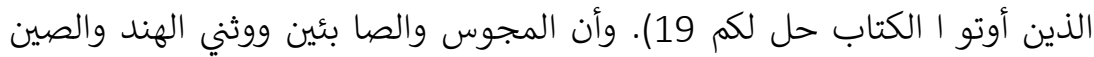

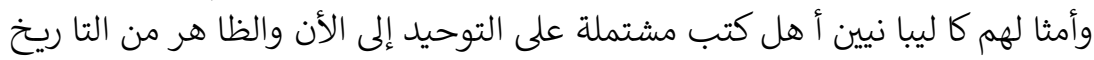

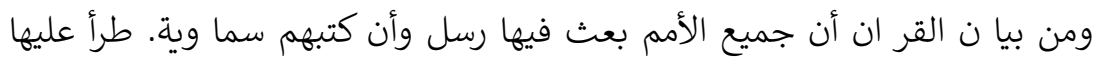

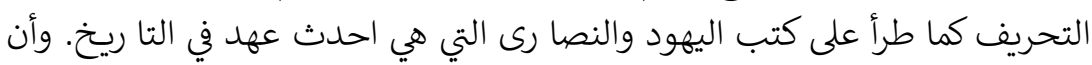

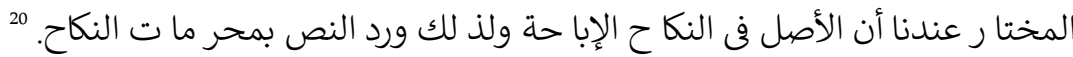

Dalam menafsirkan ayat ini, Rasyid Ridha menyatakan bahwa ahli kitab tidak hanya sebatas dua komunitas saja Yahudi dan Nasrani saja, melainkan semua penganut agama dan kepercayaan

${ }_{17}$ Ibid, hlm 283

${ }_{18}^{18}$ Depag RI, Ibid, hlm 106

${ }^{19}$ Muhammad Rasyid Ridha, Tafsir al-Manar, ( Beirut : Dar al-Kutub al-'Ilmiyyah, 1947), Juz VI, hlm 148

20 Ibid, hlm 159-160.

210 | TAJDID vol. 17, No. 2, Juli - Desember 2018 
yang memiliki dan mempedomani salah satu kitab suci merupakan ahli kitab, seperti Majusi, Shabi'un, China, dan lain-lain. Hal ini menurutnya juga berdasarkan fakta sejarah serta penjelasan dan pernyataan dari al Quran sendiri, bahwa setiap umat mempunyai rasul yang diutus kepada mereka oleh Allah SWT. Mereka juga memiliki kitab suci yang dibawa oleh nabi mereka, hanya saja terjadi penyelewengan (tabrif) terhadap kitab suci tersebut sebagaimana terjadi pada kitab suci Yahudi dan Nasrani. Apalagi hukum asal pernikahan menurut Rasyid Ridha adalah mubab (boleh). Oleh karena itu, datang nash untuk mengatur dan menjelaskan dalam hal-hal dan kasus apa saja pernikahan tersebut dilarang atau diharamkan.

Berdasarkan konsep Rasyid Ridha terhadap makna ahli kitab ini, tentu saja membolehkan pernikahan pria Muslim dengan wanita ahli kitab. Kebolehannya tidak hanya dengan wanita Yahudi dan Nasrani saja, tetapi juga dengan wanita Majusi, Hindu, China, dan penganut agama lainnya yang memiliki kitab suci. Menurut Rasyid Ridha, tidak ada perbedaan yang besar antara wanita ahli kitab dengan orang mukmin. Karena, wanita ahli kitab juga beriman kepada Allah SWT dan menyembahnya, beriman kepada para Nabi dan hari akhir serta balasannya, meyakini kewajiban berperilaku baik dan keharaman berbuat jahat. Hanya saja, perbedaan yang paling prinsipil antara mukmin dengan ahli kitab adalah keengganan mereka untuk beriman kepada Nabi Muhammad SAW dan karekteristik tauhid dan ibadah yang dibawanya. Maka, orang yang beriman dengan kenabian secara umum, tentu saja mereka mau beriman kepada nabi Muhammad SAW.

Faktor yang menyebabkan mereka terhalang untuk beriman kepada Nabi Muhammad SAW adalah ketidaktahuan mereka dengan hakikat risalah yang dibawanya, atau penentangan dan 
keingkaran mereka secara zahir, padahal hati nurani mereka meyakini kebenarannya. ${ }^{21}$

Wanita ahli kitab dinikahi oleh seorang muslim, maka ia akan hidup dibawah naungan suaminya yang muslim dan tunduk terhadap undang-undang masyarakat Islam. Sehingga lama kelamaan wanita tersebut akan terpengaruh dengan ajaran-ajaran Islam. Dan sangat diharapkan agar wanita tersebut dapat memeluk Islam stelah sekian lama ia hidup di dalam masyarakat Muslim. Akan tetapi, wanita ahli kitab yang boleh dinikahi menurut Rasyid Ridha adalah wanita yang baik-baik. Karena, kata mubshanat dalam ayat itu maksudnya adalah wanita yang terhormat ( terjaga dari perbuatan zina). ${ }^{22}$

Kebolehan menikahi wanita ahli kitab, menurut Rasyid Ridha hanya berlaku bagi pria muslim yang kuat imannya dan teguh keyakinannya. Jadi, bagi yang tidak mantap keimananya, maka tidak boleh bagi pria muslim untuk menikahi wanita ahli kitab. Karena, bisa jadi dia akan terjerumus dan terpengaruh dengan wanita tersebut yang pada akhirnya dia pindah keyakinan dengan masuk agama wanita itu. Jadi, di sini Rasyid Ridha menekankan tindakan preventifnya. ${ }^{23}$

Adapun dihalalkannya menikah dengan wanita ahli kitab tujuannya adalah untuk memperlihatkan keindahan mu'amalah umat Islam dan kemudahan syari'atnya. Hal itu bisa terwujud dengan melakukan pernikahan dengan wanita mereka. Karena, laki-laki adalah pemegang otoritas dan kekuasaan terhadap wanita. Jika mu'amalah sang suami bagus terhadap sang istri, maka itu adalah suatu pertanda bahwa agama sang suamiadalah agama yang mengajak kepada kebenaran dan kepada jalan yang lurus. Agama yang mengajarkan pemeluknya untuk bersikap adil kepada sesama

\footnotetext{
${ }^{21}$ Ibid, Juz II, hlm 284

22 Ibid, Juz VI, hlm 151

23 Ibid, Juz II, hlm 159
}

212 | TAJDID Vol. 17, No. 2, Juli - Desember 2018 
muslim dan non muslim. Agama yang mengajarkan lapang dada dalam bermu'amalah dengan orang yang berbeda. ${ }^{24}$

\section{Al-Mumtahanah ayat 10}

"Hai orang-orang yang beriman, apabila datang berbijrah kepadamu perempuan-perempuan yang beriman, Maka bendaklah kamu uji (keimanan) mereka. Allah lebih mengetahui tentang keimanan mereka;maka jika kamu telab mengetahui bahwa mereka (benarbenar) beriman Maka janganlah kamu kembalikan mereka kepada (suami-suami mereka) orang-orang kafir. mereka tiada halal bagi orang-orang kafir itu dan orang-orang kafir itu tiada halal pula bagi mereka. dan berikanlah kepada (suami suami) mereka, mabar yang telah mereka bayar. dan tiada dosa atasmu mengawini mereka apabila kamu bayar kepada mereka maharnya. dan janganlah kamu tetap berpegang pada tali (perkawinan) dengan perempuan-perempuan kafir; dan hendaklah kamu minta mahar yang telah kamu bayar; dan bendaklah mereka meminta mahar yang telab mereka bayar. Demikianlab hukum Allah yang ditetapkanNya di antara kamu. dan Allah Maha mengetahui lagi Maha Bijaksana., ${ }^{, 25}$

Di dalam tafsir al-Manar baik Muhammad Abduh maupun Rasyid Ridha tidak menyantumkan penafsiran beliau terhadap surat al-Mumtahanah ayat 10 di atas. Karena memang di dalam tafsir al-Manar penafsiran yang ditafsirkan hanya sampai surah Yusuf 53. Oleh karena itu penulis tidak menyantumkan penafsiran beliau terhadap ayat tersebut. Namun teks ayat di atas tidak jauh berbeda dengan surat al-Baqarah ayat 221 tentang pelarangan menikah dengan wanita musyrik.

\section{Penafsiran dalam tafsir al-Maraghi}

Surah al-Baqarah ayat 221

Ahmad Mustafa al-Maraghi menafsirkan ayat 221 surat alBaqarah di atas, dalam tafsirnya dia menuliskan sebagai berikut:

${ }^{24} \mathrm{Ibid}$, Juz III, hlm 282-283

${ }^{25}$ Depag RI,Ibid, hlm 549

TAJDID vol. 17, No. 2, Juli - Desember 2018 | 213 


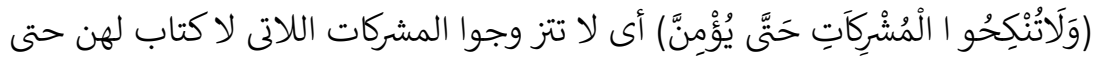

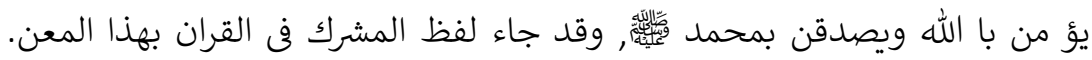

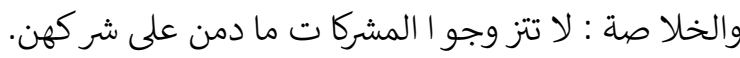

"Jangan kamu menikahi perempuan musyrik yang tidak mempunyai kitab sebagai pedoman bidup, sampai dia beriman kepada Allah SWT dan membenarkan Nabi Mubammad SAW. Lafaz, musyrik dalam al Quran dengan makna ini. Kongkritnya jangan kamu menikabi perempuan musyrik selama mereka masih di dalam kemusyrikan.

Dalam penafsirannya terhadap ayat di atas, al-Maraghi menyatakan bahwa wanita musyrik yang haram dinikahi oleh pria muslim dalam surat al-Baqarah ayat 221 tersebut adalah semua musyrik secara global, baik dari bangsa arab maupun dari non arab. Kecuali mereka mau beriman kepada Allah SWT dan Nabi Muhammad SAW. Kalau mereka tetap dengan keyakinan dan kepercayaan yang mereka anaut, maka tidak ada celah sedikitpun bagi seorang muslim untuk menjalin hubungan kekeluargaan dan tali pernikahan dengan mereka. ${ }^{26}$

Al-Maraghi menambahkan bahwa menikahi seorang budak wanita yang beriman dengan segala kekurangannya jauh lebih baik dibanding menikahi wanita musyrik, walaupun dia memiliki banyak kelebihan. Al-Maraghi mengakui bahwa kalau bisa mendapatkan istri yang cantik (cantik agama dan wajahnya), yang dengan dua hal itu dia bisa menggapai kebahagiaan dan kesempurnaan secara agama sekaligus agama, maka itu lebih bagus. Akan tetapi, jika disuruh memilih antara kecantikan dan keimanan, maka pilihlah keimanan.

Karena jika hanya mengandalkan kecantikan semata tanpa ada keimanan, maka akan berdampak buruk baginya. Keimanan lebih penting daripada kecantikan. Keimanan adalah harga mati dan

26 Ahmad Mustafa al-Maraghi,Tafsir al-Maraghi ( Mesir : Mathba'ah al-Halabiy, 1946)

214 | TAJDID Vol. 17, No. 2, Juli - Desember 2018 
segalanya. ${ }^{27}$ Wanita musyrik tidak punya panduan dalam kehidupannya untuk menentukan benar salahnya suatu tindakan. Sehingga, dia akan merasa biasa saja ketika melakukan kedurhakaan kepada suaminya. ${ }^{28}$ Oleh karena itu sudah wajar pernikahan dengan wanita musyrik akan menjerumuskan seseorang ke dalam jurang neraka. ${ }^{29}$ Secara eksplisit, ayat ini (alBaqarah ayat 221) memang menyatakan keharaman menikahi wanita musyrik. Bahkan hamba sahaya yang beriman jauh lebih dari wanita musyrik walaupun mereka sangat menakjubkan.menurut para ulama pun sejauh ini hukum pernikahan antara pria muslim dengan wanita musyrik, terutama ulama empat mazhab adalah haram. ${ }^{30}$

\section{Penafsiran surat al-Maidah ayat 05}

Ayat al Quran yang berbicara tentang pernikahan antara pria muslim dengan wanita ahli kitab termektub dalam surat al-Maidah ayat 05 :

"Pada hari ini Dihalalkan bagimu yang baik-baik. makanan (sembelihan) orang-orang yang diberi Al kitab itu halal bagimu, dan makanan kamu halal (pula) bagi mereka. (dan Dibalalkan mangawini) wanita yang menjaga kehormatan diantara wanita-wanita yang beriman dan wanita-wanita yang menjaga kehormatan di antara orang-orang yang diberi Al kitab sebelum kamu, bila kamu telah membayar mas kawin mereka dengan maksud menikabinya, tidak dengan maksud berivina dan tidak (pula) menjadikannya gundikgundik. Barangsiapa yang kafir sesudab beriman (tidak menerima bukum-bukum Islam) Maka hapuslah amalannya dan ia di hari kiamat Termasuk orang-orang merugi."

Berikut kutipan penafsiran al-Maraghi terhadap ayat di atas (al-Maidah ayat 05$)$ :

27 Ibid

${ }^{28}$ Ibid, hlm 152

29 Ibid, hlm 153

30 Muhammad Jawad Mughniyah, al Fiqh 'Ala al-Madrabib alKhomsah Fiqih Lima Mąhab (Dar al Jawad, Beirut 2011), hlm 365

TAJDID vol. 17, No. 2, Juli - Desember $2018 \mid 215$ 
المحصنا ت هنا الحرائر أى وأ حل لكم أ يها المؤ منون نكا ح الحرائر من المؤ منا ت

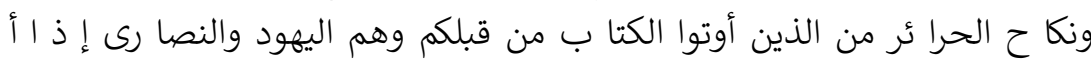
عطيتم عن ونكحتم من محصنتا تكم ومحصنا تهم مهو ر هن هن.

"Mukhsanat di dalam ayat adalah perempuan yang merdeka artinya dihalalkanbagi sekalian orang-orang mukmin menikahi perempuan yang merdeka dari golongan mukminat dan menikahi perempuan merdeka dari orang-orang yang dekat dengan kitab sebelum kamu, dan mereka adalah Yabudi dan Nasrani".

Al-Maraghi menafsirkan ayat tersebut dengan mengatakan bahwa ahli kitab hanya terbatas kepada dua komunitas Yahudi dan Nasrani saja dari keturunan siapapun mereka. Sementara penganut agama lain walaupun mereka memiliki kitab suci, tidak bisa dikatakan ahli kitab. Karena, pada dasarnya kitab suci mereka tersebut bukan kitab suci samawi. ${ }^{31}$

Agaknya al-Maraghi memasukkan semua pemeluk Yahudi dan Nasrani sebagai ahli kitab dikarenakan kedua komunitas tersebut memiliki kitab suci samawi dan mempercayai nabi yang diutus kepada mereka. Oleh karena itu, menurut al-Maraghi kebolehan menikah bagi pria muslim hanya terbatas pada wanita ahli kitab dari Yahudi dan Nasrani saja, jika wanita yang dinikahi itu sudah diberikan mas kawinnya. Sementara hukum menikahi wanita Majusi, Hindu, Budha, Konghucu, Sinto, dan lain sebagainya adalah tidak boleh atau haram. Diikatnya kehalalan menikahi dengan keharusan membayar mahar adalah sebagai penekanan bahwa mahar itu hukumnya wajib, bukan hanya sekedar syarat halal pernikahan. ${ }^{32}$

Menurut al-Maraghi, ada syarat yang harus dipenuhi jika ingin menikahi wanita ahli kitab, yaitu wanita tersebut harus baik akhlaknya. Walaupun kata mukhsanat dalam ayat itu menurut alMaraghi adalah wanita merdeka, karena khitabnya memang

31 Ahmad Mustafa al-Maraghi, Ibid, Jilid VI, hlm 59

32 Ibid

216 | TAJDID Vol. 17, No. 2, Juli - Desember 2018 
mengarah kepada mereka, nukan berarti tidak boleh menikahi wanita budak. Hal ini asalkan tujuan pernikahan ini adalah untuk saling menjaga kesucian, bukan untuk sesuatu yang nista. ${ }^{33}$ Kemudian pembolehan pernikahan ini hanya bagi pria muslim yang kokoh imannya yang dengan itu bisa mengayomi dan mendakwahi istrinya, sehingga diharapkan kelak istrinya bisa mengikuti agama suaminya. Jadi, kebolehan ini tidak berlaku bagi pria muslim yang lemah keimananya, karena kerasukan dan fitnah yang akan terjadi jika pernikhan tetap dilaksanakan. ${ }^{34}$

Hikmah dibolehkannya pria muslim menikahi wanita ahli kitab menurut al-Maraghi adalah agar mereka bisa melihat keindahan mu'amalah umat Islam terhadap mereka dan supaya mereka bisa mengetahui realistis dan elastisnya syari'at Islam. Lakilaki dalam Islam adalah pembimbing dan pengayom bagi perempuan. Jadi, jika komunikasi dan mu'amalahnya bagus dengan istrinya, maka itu sudah cukup sebagai bukti bahwa Islam mengajak umatnya untuk berlaku objektif dalam bermu'amalah dengan penganut agama yangberbeda. Islam juga mengajak umatnya untuk bersikap legowo atau berlapang hati, dan berjiwa besar terhadap agam lain. ${ }^{35}$

\section{Penafsiran surah al Mumtahanah ayat 10}

"Hai orang-orang yang beriman, apabila datang berbijrah kepadamu perempuan-perempuan yang beriman, Maka bendaklah kamu uji (keimanan) mereka. Allah lebih mengetahui tentang keimanan mereka;maka jika kamu telab mengetabui babwa mereka (benarbenar) beriman Maka janganlah kamu kembalikan mereka kepada (suami-suami mereka) orang-orang kafir. mereka tiada halal bagi orang-orang kafir itu dan orang-orang kafir itu tiada halal pula bagi mereka. dan berikanlah kepada (suami suami) mereka, mabar yang telab mereka bayar. dan tiada dosa atasmu mengawini mereka apabila

\footnotetext{
${ }^{33}$ Ibid, hlm 59

34 Ibid, Jilid II, hlm 154

35 Ibid, hlm 153
} 
kamu bayar kepada mereka maharnya. dan janganlah kamu tetap berpegang pada tali (perkawinan) dengan perempuan-perempuan kafir; dan hendaklah kamu minta mahar yang telah kamu bayar; dan hendaklah mereka meminta mahar yang telah mereka bayar. Demikianlah bukum Allah yang ditetapkanNya di antara kamu. dan Allah Maha mengetabui lagi Maha Bijaksana." ${ }^{, 36}$

Ada beberapa riwayat yang menerangkan tengan asbab an nuzul ayat di atas diantaranya sebagai berikut :

Imam Bukhari dan Muslim meriwayatkan dari al-Masur dan Marwan bin Hakam bahwa ketika Rasulallah membuat kesepakatan damai dengan orang-orang kafir Hudaibiyah, datanglah beberapa wanita mukminah kepada beliau. Lalu Allah menurunkan ayat ini. ${ }^{37}$

Imam ath- Thabari meriwayatkan dengan sanad yang lemah dari Abdullah bin Abi Ahmad yang berkata : pada masa berlangsungnya perjanjian damai (antara kaum muslimin dan kaum kafir Mekkah), Ummu Kultsum bin Uqbah bin Abi Mu'ith melakukan hijrah ke Madinah. Dua orang saudara laki-laki Ummu Kultsum yaitu Umarah dan Walid, lantas dating menemui Rasulallah dan meminta beiau untuk mengembalikan Ummu Kultsum kepada mereka. Akan tetapi Allah membatalkan perjanjian antara rasulnya dengan orang-orang musyrik tersebut, khususnya dalam masalah wanita mukminah. Dimana Allah melarang beliau untuk mengembalikan mereka kepada orangorang musyrik. Ketika itu Allah menurunkan ayat ini. ${ }^{38}$

Ibnu Abi Hatim meriwayatkan dari Yazad bin Abu al Habib bahwa yang ia dengar adalah ayat ini turun berkenaan dengan Umaimah binti Basyar istri Abu Hasan ad-Dahdahah. ${ }^{39}$ Dari

36 Depag RI, Ibid, hlm 530

37 Jalaludin ash- Sayuthi, sebab-sebab turunnya ayat al Quran ( Kairo ; Darul Taqwa) hlm 568

38 Ibid, hlm 569

${ }^{39}$ Ibid, hlm 360

218 | TAJDID Vol. 17, No. 2, Juli - Desember 2018 
Muqatil diriwayatkan bahwa ada seorang wanita bernama Saidah yang merupakan istri dari Shaifi bin Rahib seorang laki-laki musyrik di Mekkah. Wanita itu dilarang kemadinah disaat berlangsungnya kesepakatan damai. Orang-orang musyrik lantas berkata " kembalikan dia kepada kami ", sebagai responnya, maka turunlah ayat ini.

Ibnu Jarir meriwayatkan dari az- Zuhri bahwaayat ini turun berkenaan pada saat Rasulallah tengah berda di kawasan Hudaibiyah yaitu ketika beliau menyepakati bahwa jika ada penduduk Mekkah yang dating kepadanya maka beliau akan mengembalikannya kepada mereka. Akan tetapi, tatkala yang datang wanita maka turunlah ayat ini.

Berikut kutipan al-Maraghi dalam menafsirkan ayat di atas ( al-Mumtahanah ayat 10) :

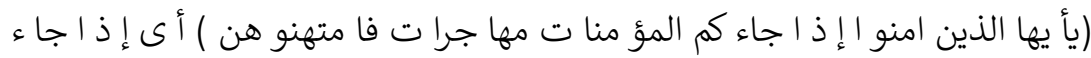

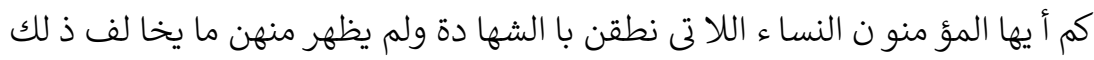

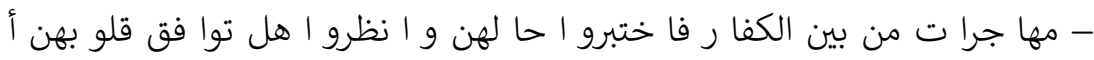

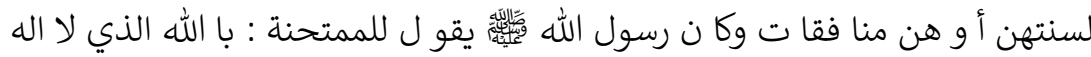

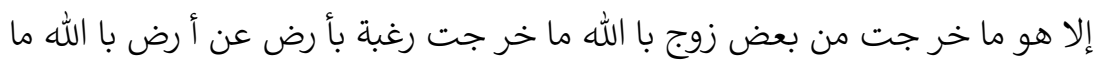

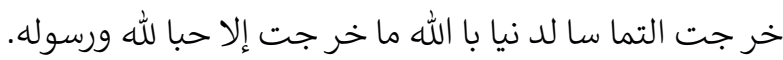

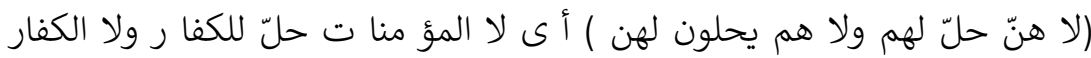

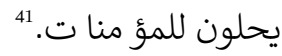

"Apabila datang kepada kamu wahai sekalian orang mukmin, wanita yang mengucapkan syahadat (persaksian), dan tidak terlibat dari mereka sesuatu yang salah, apakah ia benar-benar hijrah daripada kekufuran, maka perhatikan apakah sama antara lisan dan hati mereka, atau mereka adalah orang munafik. Dan Rasulallah $S A W$

40 Ibid, hlm 363

41 Ahmad Mustafa al-Maraghi,Tafsir al-Maraghi ( Mesir : Mathba'ah al-Halabiy, 1946), Juz 28, hlm 72

TAJDID vol. 17, No. 2, Juli - Desember $2018 \mid 219$ 
bersabda: "Demi Allah yang tidak ada tuhan selain dia, apa yang membuat kamu lari dari sebagian suami, demi Allah apakah kamu keluar untuk berpindah dari satu tempat ke temapat yang lain. Orang mukmin tidak halal bagi orang kafir dan orang kafir tidak halal bagi orang mukmin."

Al-Maraghi menafsirkan bahwa apabila datang kepadamu wahai sekalian orang mukmin wanita yang mengucapkan persaksian (syahadah) maka ujilah mereka dan tidak tampak dari mereka itu apa yang bertentangan dengan hal tersebut, sedang mereka berhijrah dari orang-orang kafir, maka ujlah keadaan mereka, dan perhatikanlah apakah hati mereka sesuai dengan lidah mereka, ataukah mereka itu wanita yang munafik. Dan adalah Rasulallah saw mengatakan kepada wanita yang diuji itu, demi Allah yang tidak ada tuhan selain dia, engkau tidaklah pergi karena kebencian kepada suami. Demi Allah, engkau tidak pergi mencari dunia. Demi Allah, engkau tidak pergi kacuali karena cinta kepada Allah dan Rasulnya.

Kemudian Allah menyebutkan kalimat sisipan (jumlah mu'taridah) antara sebelum dan sesudahnya, untuk menjelaskan bahwa ujian ujian itu berguna untuk menguji zahir saja. Senada dengan firman Allah swt :

$$
\text { الله اعلم با يما نهن }
$$

Allah lebih mengetahui iman mereka daripada kamu, dialah yang menguasai segala rahasia. Disini terdapat penjelasan bahwa tidak ada jalan untuk mengetahui hakikat iman mereka, karena hal itu termasuk urusan yang hanya diketahui oleh Allah sendiri. Wanita-wanita mukmin itu tidak halal bagi suami-suami yang kafir. Dan suami-suami yang kafir itu tidak halal pula bagi istri-istri yang mukmin. 


\section{Persamaan dan Perbedaan Metodologi dan isi penafsiran.}

Jika diperhatikan penafsiran Rasyid Ridha dan al-Maraghi terhadap ayat yang membicarakan masalah pernikahan antara pria muslim dengan wanita musyrik ini, terdapat persamaan dan perbedaan antara mereka. Diantara persamaan penafsiran antara Rasyid Ridha dan al-Maraghi antara lain adalah:

Pertama, adalah berkaitan dengan kesimpulan hukum yang mereka utarakan bahwa menikahi wanita musyrik bagi pria muslim adalah haram. Hal ini tentu saja berdasarkan informasi dari al Quran yang menyatakan secara eksplisit masalah tersebut. Kedua, dilihat dari alasan atau argumentasi yang mereka kemukakan mengenai haramnya pernikahan tersebut.

Sementara perbedaan penafsiran antara Rasyid Ridah dan alMaraghi terhadap ayat yang membicarakan tentang masalah pernikahan antara pria muslim dengan wanita musyrik ini adalah pemahaman mereka terhadap kata musyrikah yang ada di dalam ayat tersebut. Rasyid Ridha memahami bahwa kata musyrikah yang terdapat pada ayat 221 surat al-Baqarah tersebut ditujukan kepada wanita musyrik arab, sementara al-Maraghi memahami kata musyrikah di dalam ayat di atas ditujukan kepada wanita musyrik secara global.

Sementara dilihat dari segi metodologi penafsiran Rasyid Ridha dan al-Maraghi memakai metode yang sama yaitu metode tahlili. Metode tahlili adalah suatu metode yang mencoba menafsirkan ayat demi ayat dan surat demi surat sesuai dengan urutan mushaf utsmani. Namun pendekatan yang mereka gunakan dalam menafsirkan tampak berbeda. Rasyid Ridha dalam memahami kata musyrikah pada ayat di atas menggunakan pendekatan al-ibrah bi al-khusus al sabab la bi 'umum al laf₹̧hi. Oleh karena itu, dia memahami bahwa yang dimaksud dengan musyrikah pada ayat di atas adalah wanita musyrik arab ketika al

TAJDID vol. 17, No. 2, Juli - Desember 2018 | 221 
Quran diturunkan. Makanya keharaman pernikahan hanya berlaku bagi wanita musyrik arab saja, bukan yang lainnya.

Sementara al-Maraghi berpandangan bahwa kata musyrikah yang terdapat di dalam surat al-Baqarah ayat 221 tersebut adalah wanita musyrik secara global. Karena di dalam memahami ayat tersebut al-Maraghi menggunakan pendekatan al 'ibrah bi umum al lafz̧bila bi al khusus al sabab. Oleh Karena itu, al-Maraghi berpendapat bahwa haram hukumnya bagi pria muslim menikah dengan wanita musyrik. Keharamannya tidak hanya terbatas pada wanita musyrik arab saja sebagaimana yang dikatakan oleh Rasyid Ridha tetapi termasuk semua wanita musyrik yang ada didunia ini.

Didalam penafsiran Rasyid Ridha dan al-Maraghi terhadap ayat yang membicarakan tentang pernikahan pria muslim dengan wanita ahli kitab, di satu sisi mereka berada dalam kesamaan pendapat dan di sisi lain terdapat perbedaan pendapat di antara mereka. Pendapat Rasyid Ridha terkait masalah pernikahan antara pria muslim dengan wanita ahli kitan adalah boleh, begitu juga halnya dengan al-Maraghi dan ini bersifat mutlak. Menurut mereka, wanita ahli kitab memiliki kesatuan sumber agama dengan agama Islam, dan diapun (wanita ahli kitab) beriman kepada tuhan dan nabi-nabinya serta beriman pula akan adanya hari pembalasan dan akherat. Mereka juga sama-sama mengemukakan alasan atau argument bahwa kebolehannya dengan syarat yang terpenuhinya beberapa ketentuan sebagai berikut:

Wanita ahli kitab yang boleh dinikahi adalah wanita yang baik, dalam arti kata mereka adalah wanita yang menjaga kehormatannya, bukan wanita yang nakal dan binal. Dalam hal ini tidak ada bedanya wanita merdeka dan hamba sahaya. Harus membayar mahar pernikahan kepada wanita ahli kitab yang hendak dinikahi tersebut. Dan setelah dibayarkan, mahar itu sepenuhnya menjadi hak wanita tersebut. Tujuan melangsungkan pernikahan tersebut haruslah positif. Jadi, kalau tujuannya untuk hal-hal yang negatif, maka pernikahan itu tidak boleh dilaksanakan. 
Kebolehan menikahi wanita ahli kitab hanya berlaku kepada pria muslim yang kuat imannya. Karena pada dasarnya, dibolehkannya pernikahan tersebut bertujuan agar wanita ahli kitab yang sudah menjadi istri bagi pria muslim, bisa beralih menjadi wanita muslimah. Kalau dikhawatirkan pernikahan tersebut berdampak buruk bagi bagi pria muslim, maka tidak boleh melakukannya. Karena tindakan preventif lebih diutamakan dalam Islam. Perbedaan penafsiran antara Rasyid Ridha dan alMaraghi dalam menafsirkan surat al Maidah ayat 05 terletak pada dua hal :

Pertama, mereka berbeda dalam memaknai kata mukbsanat yang ada dalam ayat tersebut. Rasyid Ridha memilih bahwa yang dimaksud dengan mukhsanat dalam ayat adalah wanita yang terhormat. Hal ini dinyatakan Rasyid Ridha setelah dia memaparkan panjang lebar tentang perbedaan yang terjadi antara ulama dalam masalah ini. Pada akhirnya dia enyatakan bahwa endapat yang kuat adalah pendapat yang menafsirkan kata itu dengan wanita yang terhormat bukan wanita merdeka. Sementara al-Maraghi secara gamblang menyatakan bahwa yang dimaksud dengan mukhsanat dalam ayat tersebut adalah wanita merdeka. AlMaraghi tidak menjelaskan perbedaan pendapat ulama dalam masalah ini. Karena memang salah satu ciri khas dari tafsir alMaraghi adalah ringkas dan tidak panjang lebar dalam mebahas suatu masalah.

Kedua, mereka berbeda dalam defenisi yang dipakai tentang ahli kitab. Rasyid Ridha memaknai ahli kitab adalah semua agama yang memiliki kitab suci untuk dijadikan pedoman. Jadi, kriteria ahli kitab menurut Rasyid Ridha adalah asalkan mempunyai kitab suci. Sedangkan al-Maraghi memaknai ahli kitab adalah umat Yahudi dan Nasrani saja, tanpa memberikan kriteria yang lebih rinci atau mensyaratkan bahwa wanita ahli kitab tersebut harus memnuhi kritria tertententu sebagaimana yang dikemukakan oleh ulama yang lain seperti Syafi'i.

TAJDID vol. 17, No. 2, Juli - Desember 2018 | 223 
Melihat pendapat al-Maraghi tentang ahli kitab yang membatasi maknanya pada golongan Yahudi dan Nasrani saja, maka dapat penulis simpulkan bahwa:

Pertama, seseorang yang menganut agama ahli kitab sebelum al Quran diturunkan maupun sesudahnya, sebelum mengalami perubahan maupun sesudah mengalami perubahan, termasuk dalam kategori ahli kitab. Kedua, kelompok ahli kitab ini tidak hanya sebatas jazirah arab saja, tempat para nabi diutus oleh Allah, tetapi juga termasuk mereka yang berada diluar jazirah arab. Jadi, orang Yahudi di Israel dan dimanapunm mereka berada, begitu juga orang nasrani di Indonesia meraka termasuk kedalam golongan ahli kitab. Ketiga, walaupun agama Yahudi dan Nasrani diperuntukkan bagi orang-orang Israel, tetapi al-Maraghi tetap memasukkan orang-orang diluar etnis Israel, yang menganut agama Yahudi dan Nasrani sebagai ahli kitab. Dari pemaparan diatas ada beberapa poin yang dapat penulis kemukakan dalam penelitian ini sebagai analisis penulis terhadap perbedaan penafsiran antara tafsir al-Manar dan al-Maraghi :

Penafsiran Rasyid Ridha terhadap surat al-Baqarah ayat 221 ini penulis rasa tidak relavan, kalau dilihat dari segi relevansinya dengan kehidupan modern. Karena bisa diketahui dalam sejarah bahwa semua jazirah arab sudah memeluk Islam sebelum Nabi wafat. Puncaknya ketika fathu Makkah semua orang berbondongbondong memluk agama Islam. Oleh karena itu bisa dipastikan bahwa sekarang wanita musyrik arab tidak ada lagi. Sementara penafsiran al-Maraghi lebih relevan dengan zaman modern. Karena, sampai saat sekarang orang musyrik masih ada dan jumlah mereka sangat banyak.

Untuk memperjelas analisis komparasi antara kedua mufassir ini, maka penulis menampilkan table komparasi sebagai berikut:

Kemudian dari penafsiran Rasyid Ridha dan al-Maraghi tentang masalah bolehnya pernikahan pria muslim dengan wanita 
ahli kitab, dapat penulis fahami bahwa mereka sama-sama menggunakan pendekatan takbsis al-ayah bi al-ayah. Ayat yang melarang pernikahan beda agama secara umum dengan wanita musyrik dalam surat al-Baqarah ayat 221 sebenarnya tidak mencakup wanita ahli kitab, meskipun mereka dalam keimanannya telah terkontaminasi dengan konsep keimanan yang menjurus kepada kemusyrikan. Karena dalam dalam ayat lain, surat alMaidah ayat 05 dinyatakan kebolehan menikahi mereka. Artinya, surah al-Maidah ayat 05 ini memberi pengkhususan (takhsis) bahwa larangan menikah dengan wanita musyrik dalam surah al-Baqarah ayat 221 tidak berlaku terhadap wanita ahli kitab.

Dilihat dari relevansinya, penulis menganggap bahwa penafsiran Rasyid Ridha mungkin bisa diterapkan di Indonesia. Karena, Indonesia menaungi banyak agama besar di dunia dan negara yang berpenduduk Muslim terbesar di dunia. Di Indonesia terdapat agama Islam, Katolik, Protestan, Hindu, Budha, dan Konghucu yang mana semua agama ini memiliki kitab suci yang mereka yakini kebenarannya. Begitu juga dengan penafsiran alMaraghi yang menyatakan ahli kitab itu hanya Yahudi dan Nasrani saja. Di Indonesia orang Nasrani cukup banyak. Untuk memperjelas analisis komparasi penafsiran antara kedua tafsir ini, maka penulis rasa perlu menampilkan tabel komparasi sebagai berikut:

\begin{tabular}{|c|c|c|c|}
\hline No & Komparasi & Rasyid Ridha & Al-Maraghi \\
\hline 1 & persamaan & $\begin{array}{c}\text { Boleh nikah dengan } \\
\text { wanita ahli kitab }\end{array}$ & $\begin{array}{c}\text { Boleh nikah dengan } \\
\text { wanita ahli kitab }\end{array}$ \\
\hline 2 & Perbedaan & $\begin{array}{c}\text { Ahli kitab setiap } \\
\text { agama yang } \\
\text { memiliki kitab suci }\end{array}$ & $\begin{array}{c}\text { Ahli kitab Yahudi dan } \\
\text { Nasrani saja. }\end{array}$ \\
\hline 3 & $\begin{array}{c}\text { Metodolog } \\
\text { Takhsis al-ayah bi } \\
\text { al-ayah } \\
\text { (mengkhususkan }\end{array}$ & $\begin{array}{c}\text { Takhsis al-ayah bi al- } \\
\text { ayah } \\
\text { (mengkhususkan satu }\end{array}$ \\
\hline
\end{tabular}

TAJDID Vol. 17, No. 2, Juli - Desember 2018 | 225 


\begin{tabular}{|c|c|c|c|}
\hline & & $\begin{array}{c}\text { satu ayat dengan } \\
\text { ayat yang lain) }\end{array}$ & $\begin{array}{c}\text { ayat dengan ayat yang } \\
\text { lain) }\end{array}$ \\
\hline 4 & Relevansi & Relevan & Relevan \\
\hline
\end{tabular}

Namun, berdasarkan fakta yang ada ditengah-tengah masyarakat yang melakukan pernikahan dengan ahli kitab pada zaman sekarang ini, apalagi ahli kitab versi Rasyid Ridha, penulis tidak berada dalam satu pandangan dengan pendapat yang membolehkan pernikahan pria muslim dengan wanita ahli kitab, walaupun dengan berbagai syarat dan ketentuan yang mereka rumuskan, seperti kebolehan Cuma berlaku kepada pria muslim yang kuat imannya. Menurut penulis, ketentuan dan syarat itu tidak bisa dijadikan landasan yang kuat dan masih dipertanyakan. Pandangan penulis berdasarkan pada berbagai argumentasi adalah:

Kalau syarat bolehnya pria mullim menikahi wanita ahli kitab adalah harus bagus agamanya. Masalahnya, apakah ada jaminan bahwa setelah menikah nanti ia tidak terpengaruh oleh agama istrinya yang ahli kitab, walaupun sebelum menikah ia menyanggupinya. Jadi siapa yang bisa menjamin pria ini masih bisa tetap konsisten dengan keimananya. Karena, godaan wanita sangat kuat, apalagi kalau wanita ahli kitab tersebut mempunyai semangat dakwah yang tinggi pula untuk mengajak si pria masuk kedalam agamanya. Ditambah lagi setiap orang bisa mengklaim bahwa agamanya bagus, agar dia juga diperbolehkan melakukan pernikahan dengan wanita ahli kitab. Tapi pada akhirnya mudharatnya yang terjadi. Faktanya para ulama tidak berada dalam satu pendapat tenytang hukum menikahi wanita ahli kitab.

Dalam penelitian ini penulis juga tidak sependapat dengan Rasyid Ridha terkait kriteria ahli kitab yang dikemukakannya. Yaitu asalkan punya kitab suci bisa digolongkan kepada ahli kitab. Pendapat Rasyid Ridha yang menyatakan ahli kitab adalah semua agama yang mempunyai kitab suci, tidak populer dikalangan 
ulama. Karena pada prakteknya sangat sulit untuk mengetahui apakah kitab suci suatu agama yang tidak secara tegas disebutkan dalam al Quran (Taurat, Zabur, Injil dan al Quran) merupakan wahyu dari Allah SWT yang kemudian diselewengkan, atau murni pikiran manusia. Penulis lebih sependapat dengan al-Maraghi yang menyatakan bahwa ahli kitab itu hanya terbatas pada dua komunitas saja, yaitu Yahudi dan Nasrani.

\section{Penutup}

Dalam menafsirkan ayat-ayat tentang pernikahan beda agama ini tafsir al Manar mengemukakan bahwa dalam surah al Baqarah ayat 221 kata musyrikah yang terdapat dalam ayat tersebut ditafsirkan sebagai wanita musyrikah arab saja. Sedangkan al Maraghi menafsirkan kata musyrikah di dalam ayat tersebut sebagai wanita musyrikah secara umum. Kemudian dalam menafsirkan surah al Maidah ayat 05 dalam tafsir al Manar menafsirkan kata mukhsanat sebagai perempuan yang terhormat. Sedangkan di dalam tafsir al Maraghi menafsirkan kata mukhsanat sebagi wanita yang merdeka.

Apabila dilihat lebih lanjut, kedua tafsir ini dalam menafsirkan ayat-ayat pernikahan beda agama terdapat persamaan dan perbedaan. Persamaannya dapat dilihat dari kesimpulan akhir yang mereka ambil tentang penafsiran ayat-ayat nikah beda agama.Di dalam kedua tafsir ini hanya berbeda dalam memahami kata musyrikah pada surat al Baqarah ayat 221 dan kata mukhsanat dalam surah al Maidah ayat 05 . Dan perbedaan pendekatan yang digunakan keduanya dalam menafsirkan ayat tersebut. Didalam tafsir al Manar memakai pendekatan al Tbrab bi Umum al sabab la bi al khusus al sabab. Sedang dalam tafsir al Maraghi memakai pendekatan al ibrah bi 'umum al lafizi la bi al khusus al sabab. 


\section{Daftar Pustaka}

al-Maraghi, Ahmad Mustafa. Tafsir al-Maraghi ( Mesir : Mathba'ah al-Halabiy, 1946)

Ash Shayuti, Jalaludin. Libabun Nuqulil Fii Asbabin Nuzul, Sebabsebab Turunnya Ayat al Quran (Kairo : Darul Taqwa)

Al-Thabari, Jami' al-Bayan fi Ta'wil al Quran ( Cairo : Dar Hijr, 2001), Cet. I, Jilid III.

Depag RI, al-Quran dan Terjemahannya, Jakarta : Yayasan Penyelenggara Penterjemah/ Pentafsir al-Quran , 1971

Mughniyah, Muhammad Jawad. al Fiqh 'Ala al-Madzahib alKhomsah Fiqih Lima Mazhab (Dar al Jawad, Beirut 2011.

Muhammad Rasyid Ridha, Tafsir al-Manar, ( Beirut : Dar al-Kutub al-'Ilmiyyah, 1947), Juz VI.

Ridla, Muhammad Rasyid. Tafsir al-Manar (Beirut: Dar al-Kutub al-'Ilmiyah, 1947). Cet . I,Juz II.

------, Tafsir al-Maraghi (Mesir : Mathba'ah al-Halabiy, 1946), Juz 28. 